\title{
The hidden perils of lead in the lab: Guidelines for containing, monitoring and decontaminating lead in the context of perovskite research
}

Michael Salvador*, Christopher E. Motter, Iain McCulloch

\section{Author Information}

Corresponding Authors

Michael Salvador - King Abdullah University of Science and Technology (KAUST),

KAUST Solar Center, Thuwal, Saudi Arabia; Email: michael.salvador@kaust.edu.sa

Authors

Iain McCulloch - King Abdullah University of Science and Technology (KAUST), KAUST

Solar Center, Thuwal, Saudi Arabia; Department of Chemistry and Centre for Plastic

Electronics Imperial College London, London W12 OBZ;

Christopher E. Motter - King Abdullah University of Science and Technology (KAUST), Health, Safety and Environment, Thuwal, Saudi Arabia. 


\begin{abstract}
The metal lead is an integral part of mainstream perovskite solar cells. Lead-based compounds in the form of lead-based paint and lead-contaminated dust are known to potentially trigger long lasting health implications when exposure surpasses certain limits and lead is accumulated in the human body. Because it is not clear what the health implications are of lead that is processed in the context of perovskite research and no organization has published specific directives, we have established a set of instructions for lead safety in perovskite research labs. The instructions include best practices for handling, containing, monitoring and decontaminating lead-based materials. Importantly, it is shown that lead can be contained best by adopting strict cleaning and housekeeping protocols, while decontamination can be accomplished with conventional detergents. Reliable testing of contamination levels requires periodic chemical analysis such as ICP (inductively coupled plasma spectroscopy). Conversely, simple lead tests that are currently on the market can lead to misleading assessment. We further recommend periodic medical surveillance in the form blood lead level testing to ensure the well-being of lab users. The directives described here were established such that they can be easily adopted by any lab working on perovskite research.
\end{abstract}




\section{Introduction}

Perovskite solar cells have garnered enormous excitement over the last decade, arising from their ease of fabrication, high performance and rapid performance improvement. ${ }^{1,2}$ As the number of research and development groups actively engaged in this field continues to increase, the safe handling, exposing and disposal of the toxic lead salts used in these devices becomes a more prominent issue. While students and researchers are usually familiar with the general idea that lead can be toxic, very little awareness is often demonstrated towards the potential hazards associated with lead contamination in the lab, particularly around lead-based device fabrication. This article provides guidance on how to best control lead contamination in the form of the most commonly used lead salts in the context of mainstream perovskite research that is happening today across many labs in the world. The procedures described herein emerged from the experience gained in our labs over the past several years. The text reflects our discussions with health, safety and environment (HSE) experts, observations of exposure routes in the lab, quantitative results of lead contamination and spread in perovskite research labs, and interpretation on how to best contain, monitor and decontaminate lead compounds in the form of solids (powders) and solutions. We note that this is not an allcomprehensive safety instruction bulletin, but rather an attempt to highlight less-obvious dangers, and offer practical solutions for researchers to consider and utilize. These guidelines provide laboratory users of lead compounds information on how to implement our decontamination procedures. Utilizing these procedures and methods will reduce lead levels in the lab and thereby reduce lab user's potential exposure to harmful lead.

Lead(II) salts are precursors of lead-based perovskite semiconductors. In a typical perovskite research lab, spillage of trace amounts of lead powder is unavoidable. Unlike a simple spill of a benign chemical, spills of lead compounds can expose researchers to levels of lead that can be harmful. ${ }^{3}$ Lead(II) salts can be toxic and are suspected carcinogens. ${ }^{4,5}$ Lead can also accumulate in the body through bioaccumulation in bone and other tissues. ${ }^{6}$ It can cause a variety of well documented health problems and can even ultimately result in death. ${ }^{7}$ Moreover, lead salts are most commonly provided in the form of fine powders that can easily become airborne and spread across large distances in the lab. Solvents which are commonly used to prepare perovskite formulations, such as dimethylformamide (DMF) and 
dimethylsulfoxide (DMSO) can significantly exacerbate the intoxication of lead compounds as they are particularly effective in enhancing skin permeability, thus increasing the risk of absorption via dermal contact. ${ }^{8}$ In addition, it is important to realize that contaminated clothing can also transport lead from the lab leading to secondary exposure. Therefore, controlling lead levels at the source is vital in order to reduce lead exposures.

The motivation to draft these guidelines stems from a current lack of clear directions on lead work in a laboratory/research setting from a regulatory body, at least from one that is accessible and widely adopted by the perovskite research community. Instead, there are publications by a range of health and safety organizations that are based on, e.g., permissible amounts of lead on surfaces and in the air and reference blood lead levels. However, published values, and respective directives, differ widely from agency to agency ${ }^{9,10}$ and do not account for the work environment of modern research labs, leading to an existing uncertainty around lead safety in labs. For instance, the National Institute of Occupational Safety and Health (NIOSH) and the Occupational Safety and Health Administration (OSHA) have set action levels of 5 and $50 \mu \mathrm{g} / \mathrm{dL}$ of lead in blood, respectively. Table 1 compiles the stated permissible amounts of lead according to different health and safety agencies. Moreover, we found that current regulations typically refer to lead embedded in a material mixture, e.g., lead paint, and therefore allude to breathing dust containing lead arising from scraping, grinding, etc. of such lead paint. According to OSHA, the action level for workers in contact with lead (measured in $\mu \mathrm{g} / \mathrm{m}^{3} / 8 \mathrm{hr}$ time weighted average) is $30 \mu \mathrm{g} / \mathrm{m}^{3} / 8 \mathrm{hr}$ and the permissible exposure level is $50 \mu \mathrm{g} / \mathrm{m}^{3} / 8 \mathrm{hr} .{ }^{11}$ However, continuous exposure to lead in the air during an 8 -hour workday is not the route of exposure that researchers encounter in common perovskite research labs.

Alarmingly, a recent cohort study by Lanphear et al. ${ }^{12}$ reported an attributable fraction of blood lead levels to all-cause mortality among US adults of $18 \%$, pointing to potential health implications at levels much lower than the guidelines defined, for instance, by OSHA. ${ }^{12,13}$ In this context, we cite text from the Association of Occupational and Environmental Clinics (AOEC): "Although the Federal Occupational Safety and Health Administration's lead standards have provided guidance that has been beneficial for leadexposed workers, these regulations have not been substantially changed since the late 1970s 
and thus are primarily based on health effects studies that are well over three decades old. There is an urgent need to revise them." 14 As such, current regulations are outdated and do not account for the much more concentrated forms of lead ( $>97 \%$ purity) and its diffusivity (in the form of loose powders). Considering these limitations, we drafted procedures, which are shared here, evolving from experiences within our groups and collaborators.

Table 1. Permissible amounts of lead on surfaces, in the air, in food, and reference blood lead levels according to different health and safety agencies in the US, Canada, UK, Germany, Europe and global agencies. Adapted from references ${ }^{9,10}$.

\begin{tabular}{|c|c|c|c|}
\hline & \multicolumn{3}{|c|}{ Lead Level Action Thresholds for Differing Agencies and Media } \\
\hline Media & Agency & Lead Levels & Notes \\
\hline $\begin{array}{l}\text { Air } \\
\text { (workplace) }\end{array}$ & $\mathrm{ACGIH}^{\mathrm{a}}$ & $\begin{array}{l}150 \mu \mathrm{g} / \mathrm{m}^{3} \\
50 \mu \mathrm{g} / \mathrm{m}^{3}\end{array}$ & $\begin{array}{l}\text { TLV/TWA }{ }^{\mathrm{b}} \text { guideline for lead arsenate } \\
\text { TLV/TWA }{ }^{\mathrm{b}} \text { guideline for other forms of } \\
\text { lead }\end{array}$ \\
\hline $\begin{array}{l}\text { Air } \\
\text { (workplace) }\end{array}$ & $\mathrm{CCOHS}^{\mathrm{c}}$ & $50 \mu \mathrm{g} / \mathrm{m}^{3}$ & TLV-TWA ${ }^{\mathrm{b}}$ \\
\hline $\begin{array}{l}\text { Air } \\
\text { (workplace) }\end{array}$ & $\begin{array}{l}\mathrm{EEC}^{\mathrm{d}} \\
\text { Directive 98/24 }\end{array}$ & $150 \mu \mathrm{g} / \mathrm{m}^{3}$ & $\begin{array}{l}\text { Occupational exposure limit value, } 8 \mathrm{~h} \\
\text { time-weighted average }\end{array}$ \\
\hline $\begin{array}{l}\text { Air } \\
\text { (ambient) }\end{array}$ & EPA $^{\mathrm{e}}$ & $0.15 \mu \mathrm{g} / \mathrm{m}^{3}$ & Regulation; NAAQSf; 3-moth average \\
\hline $\begin{array}{l}\text { Air } \\
\text { (workplace) }\end{array}$ & $\mathrm{HSE}^{\mathrm{g}}$ & $150 \mu \mathrm{g} / \mathrm{m}^{3}$ & Action level (8-h time-weighted average) \\
\hline $\begin{array}{l}\text { Air } \\
\text { (workplace) }\end{array}$ & $\mathrm{NIOSH}^{\mathrm{h}}$ & $50 \mu \mathrm{g} / \mathrm{m}^{3}$ & $\mathrm{REL}^{\mathrm{i}}$ (non-enforceable) \\
\hline $\begin{array}{l}\text { Air } \\
\text { (workplace) }\end{array}$ & OSHA $^{\mathrm{j}}$ & $\begin{array}{l}50 \mu \mathrm{g} / \mathrm{m}^{3} \\
30 \mu \mathrm{g} / \mathrm{m}^{3}\end{array}$ & $\begin{array}{l}\text { Regulation; PELw (8-hour time weighted } \\
\text { average) (general industry) } \\
\text { Action level (averaged over an 8-hour } \\
\text { period) }\end{array}$ \\
\hline $\begin{array}{l}\text { Air } \\
\text { (workplace) }\end{array}$ & SCOEL ${ }^{k}$ & $100 \mu \mathrm{g} / \mathrm{m}^{3}$ & Action level (8-h time-weighted average) \\
\hline Blood & ACGIH & $30 \mu \mathrm{g} / \mathrm{dL}$ & Advisory; indicates exposure at TLV \\
\hline Blood & EEC & $70 \mu \mathrm{g} / \mathrm{dL}$ & Recommended limit for BLL ${ }^{1}$ \\
\hline Blood & Health Canada & $10 \mu \mathrm{g} / \mathrm{dL}$ & Blood lead intervention level \\
\hline Blood & HSE & $\begin{array}{l}25 \mu \mathrm{g} / \mathrm{dL} \\
40 \mu \mathrm{g} / \mathrm{dL} \\
50 \mu \mathrm{g} / \mathrm{dL}\end{array}$ & $\begin{array}{l}\text { Action levels } \\
\text { Women of reproductive age } \\
\text { People } 16-17 \text { years old } \\
\text { All other groups }\end{array}$ \\
\hline
\end{tabular}




\begin{tabular}{|c|c|c|c|}
\hline Blood & $\mathrm{MAK}^{\mathrm{m}}$ & $300 \mu \mathrm{g} / \mathrm{dL}$ & $\begin{array}{l}\text { BLW }{ }^{\mathrm{n}} \text { : Women }>45 \text { yrs and men } \\
\text { BAR }^{\circ} \text { : applies to women } \\
\text { Does not apply to lead arsenate, lead chromate and alkyl } \\
\text { lead compounds }\end{array}$ \\
\hline Blood & NIOSH & $5 \mu \mathrm{g} / \mathrm{dL}$ & $\begin{array}{l}\text { Reference range upper value for children's } \\
\text { BLL }{ }^{1} \text { and reference BLL for adults } \\
\text { according to ABLES }\end{array}$ \\
\hline Blood & OSHA & $\begin{array}{l}40 \mu \mathrm{g} / \mathrm{dL} \\
50 \mu \mathrm{g} / \mathrm{dL} \text { and } \\
60 \mu \mathrm{g} / \mathrm{dL}\end{array}$ & $\begin{array}{l}\text { Regulation; cause for written notification } \\
\text { and medical exam and return to work after } \\
\text { removal. } \\
\text { Regulation; cause for medical removal } \\
\text { from exposure }\end{array}$ \\
\hline Blood & SCOEL & $30 \mu \mathrm{g} / \mathrm{dL}$ & Recommended limit for BLL ${ }^{1}$ \\
\hline $\begin{array}{l}\text { Drinking } \\
\text { water }\end{array}$ & EPA & $\begin{array}{l}15 \mu \mathrm{g} / \mathrm{L} \\
0 \mu \mathrm{g} / \mathrm{L}\end{array}$ & $\begin{array}{l}\text { Action level for public supplies } \\
\text { Non-enforceable goal; } \text { MCLG }^{\mathrm{q}}\end{array}$ \\
\hline $\begin{array}{l}\text { Drinking } \\
\text { water }\end{array}$ & FDA $^{\mathrm{r}}$ & $5 \mathrm{ppb}$ & Bottled water \\
\hline Food & FDA & Various & $\begin{array}{l}\text { Action levels for various foods; example: } \\
\text { lead in candy should be limited to a } \\
\text { maximum level of } 0.1 \mathrm{ppm} \text { and in juice to } \\
50 \mathrm{ppb} \text {; action level of } 0.5 \mu \mathrm{g} / \mathrm{dL} \text { for lead } \\
\text { in infant food products; lead-soldered food } \\
\text { cans now banned; }\end{array}$ \\
\hline Food & $\mathrm{JECFA}^{\mathrm{s}}$ & $\begin{array}{l}25 \mu \mathrm{g} / \mathrm{kg} \\
\text { body } \\
\text { weight/week }\end{array}$ & $\begin{array}{l}\text { Provisional Tolerable Weekly Intake } \\
\text { (PTWI) }\end{array}$ \\
\hline Paint & $\mathrm{CPSC}^{\mathrm{t}}$ & $\begin{array}{l}90 \mathrm{ppm} \\
(0.009 \%)\end{array}$ & $\begin{array}{l}\text { Regulation; by dry weight. New standard } \\
\text { for lead in household paint and similar } \\
\text { surface coatings in children's products, } \\
\text { and some furniture, for adult and children, } \\
\text { children's toys, jewelry, etc. }\end{array}$ \\
\hline $\begin{array}{l}\text { Soil } \\
\text { (residential) }\end{array}$ & EPA & $\begin{array}{l}400 \mathrm{ppm} \\
\text { (play areas) } \\
1200 \mathrm{ppm} \\
\text { (non-play } \\
\text { areas) }\end{array}$ & $\begin{array}{l}\text { Soil screening guidance level; requirement } \\
\text { for federally funded projects only ( } 40 \text { CFR } \\
\text { Part } 745,2001 \text { ) }\end{array}$ \\
\hline Floors & $\begin{array}{l}\text { EPA and } \\
\text { HUD }^{v}\end{array}$ & $108 \mu \mathrm{g} / \mathrm{m}^{2}$ & $\begin{array}{l}\text { Hard-surfaced and carpeted; New hazard } \\
\text { standards for lead in paint, dust and soil, } \\
\text { starting June 21, } 2019\end{array}$ \\
\hline
\end{tabular}

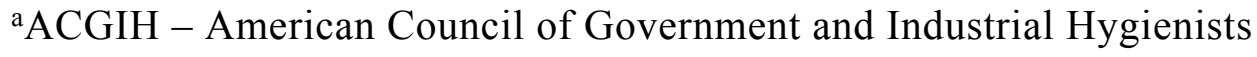




\author{
bTLV/TWA - Threshold Limit Value/Time Weighted Average \\ ${ }^{\mathrm{c} C C O H S}$ - Canadian Centre for Occupational Health and Safety \\ ${ }^{\mathrm{d} E E C}$ - European Council \\ eEPA - Environmental Protection Agency \\ fNAAQS - National Ambient Air Quality Standards \\ gHSE - United Kingdom Health and Safety Executive \\ hNIOSH - National Institute of Occupational Safety and Health \\ ${ }^{i}$ REL - Recommended Exposure Limit \\ jOSHA - Occupational Safety and Health Administration

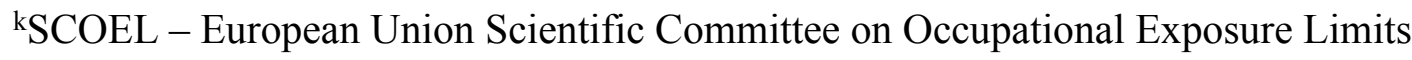 \\ ${ }^{1}$ BBL - blood lead level
}

mMAK - German Commission for the Investigation of Health Hazards of Chemical Compounds in the Work Area

${ }^{n B L W}$ - Biological guidance value (work related exposure)

${ }^{\mathrm{o} B A R}$ - Biological reference value (not work related)

pABLES - Adult Blood Lead Epidemiology and Surveillance

9MCLG - Maximum Contaminant Level Goal

${ }^{\mathrm{r}}$ FDA - Food and Drug Act

sJECFA - U.N. Food and Agriculture Organization (FAO)/ World Health Organization (WHO)

Expert Committee on Food Additives

${ }^{\mathrm{t}} \mathrm{CPSC}$ - Consumer Products Safety Commission

vHUD - U.S. Department of Housing and Urban Development

wPEL - Permissible Exposure Level 


\section{Preventing exposure to the Hazard}

Controlling exposures to lead and lead products begins with the provision of education and training for all lab personnel about the hazards of working with lead. At the KAUST Solar Center (KSC), mandatory training is required before access is granted to the lab, in conjunction with KAUST's Department for Health, Safety and Environment. The training includes an educational text and an online quiz that requires successful completion. In addition, KSC drafted a standard operating procedure (SOP) for the handling of lead-based materials, complementing this training with considerations on the usage of required engineering controls, work practices and handling techniques as well as personal protective equipment (PPE) while working with lead-based materials. Part of the SOP details a mandatory blood lead level surveillance program for those who work with lead-based materials. These combined, compulsory measures help to ensure all lab personnel are alerted to work requirements prior to commencement. All KSC educational material is made available online from our website. ${ }^{15}$

Mandatory personal protective equipment (PPE), consisting of lab coat, goggles, gloves and shoes are required for all lab related activities, be it research or periodic cleaning of lab surfaces. A separate contained space for storing PPE for lead users is advisable. We highlight the necessity of double gloving (ideally with extended cuff) when handling lead solutions because solvents such as DMF and DMSO can permeate conventional nitrile gloves with surprising velocity. ${ }^{16}$ Still, while other gloves such as butyl rubber or silver shielded gloves may feature smaller permeation rates (better barriers), depending on solvent and manufacturer, nitrile gloves offer the best general protection and a combination of good affordability, availability and practical disposability. ${ }^{3}$ Detailed information about suitable choices for PPE can be found in the online presence of NIOSH under personal protective equipment. Specialized PPE for lead decontamination is mentioned further below.

Beyond PPE, the proficient use of engineering controls is critically important for preventing any exposure to lead solids. Gloveboxes provide a contained (inert) environment for working 
with air-oxygen-water reactive reagents, making for an effective control device for working with lead-based materials by containing dusts. Given the toxicity and airborne nature of lead powders and the inherent risk for cross-contamination, we recommend all work with lead powders, especially the preparation of lead salt solutions, to be carried out exclusively inside gloveboxes dedicated to perovskite use only. Appropriate signage should inform users where lead-based materials are being worked with. Early on, we observed the highest levels of contamination and spreading of lead material emanating from areas with balances installed in open atmospheric locations, even with balance enclosures in place. Moving all balances inside gloveboxes decisively inhibits the spreading of lead material across the lab. Yet, most gloveboxes are designed such that antechambers are vented with nitrogen coming from the inside of the glovebox. This creates the possibility to deposit lead powders inside the antechamber on the tray and walls. Thus, cleaning the antechamber after every usage will diminish the chances for contamination. We also recommend fitting the nitrogen purge line of the antechamber with a particulate filter with suitable pore size (we use Swagelok ultrahigh purity gas filters for which the manufacturer specifies a removal rating of $>99.99 \%$ for particulates of $0.003 \mu \mathrm{m}$; note, the filter reduces the nitrogen flow rate). For the same reasons, disposable gloves should be worn in conjunction with the rubber gloves of the gloveboxes. Isolating lead waste inside the glove box, with one or more zip-lock bags, and disposing sharps in a hard-plastic container is an easy and effective way to further reduce contamination. The waste should be disposed of in dedicated hazardous waste containers and should be handled in accordance with reigning regulations for hazardous waste treatment.

We have evaluated the use of secondary containment to prevent lead spreading. We found that it can be useful, especially for transportation. However, it can also promote spreading lead, if not handled appropriately. For instance, in antechamber use, if lead powder happens to deposit inside the antechamber during the venting mechanism, it may promote spreading of lead contamination out of the glovebox. Frequent wet cleaning of the antechamber is more effective in this case.

In fume hoods, good housekeeping with regular cleaning is again vital. We find it helpful to cover the working area with high liquid absorbency paper (e.g. Whatman high absorbency protector) which we replace at the end of each day. 
Creating separate lab spaces for designated work practices and handling techniques involving lead has proven particularly effective, especially in preventing cross-contamination. In areas of heavy usage, stricter requirements are imposed, for example, by introducing the requirement for head covers, disposable boots and adhesive dust mats by the entrance doors. These labs or lab areas should be clearly labelled for identification. Ideally, sets of laboratories should be set up in a manner that isolates work type and equipment, e.g. a Wet Lab, Device Fabrication Lab, Characterization Lab, etc. Lead clean up material, e.g., wet wipes, should be placed throughout the labs for quick and periodic cleaning and should be disposed of in the same way as lead contaminated waste. 
Figure 1. Stepwise graphical representation of how to safely remove used gloves. The first step requires pinching the glove at the wrist level, pulling it away from the skin and then peeling it away from the hand, allowing it to turn inside out. After securing the removed glove, the ungloved hand is used to remove the other glove by sliding the fingers of the ungloved hand between the glove and the skin of the wrist and rolling the second glove down the hand. Adapted from Centers for Disease Control and Prevention. ${ }^{17}$ Figure 1 was created by Heno Hwang, scientific illustrator at King Abdullah University of Science and Technology (KAUST).

It is reinforced that PPE is only a temporary barrier for protection. Therefore, gloves must be changed often and in a way that minimizes the chances for skin contact. A safe way of removing used gloves is depicted in Figure 1. We believe disposal of contaminated lab coats following the same protocols used with hazardous waste is necessary for the sake of preventing contamination of drain water, which is a possibility when opting for a laundry service for cleaning.

In summary, minimizing the handling of lead in open atmospheric locations (fume hoods, bench tops, etc.) combined with stringent housekeeping practices, by cleaning up surfaces after every lead handling process will greatly reduce the risk for lead spreading.

\section{Contamination Testing and Decontamination}

Lab surface testing for lead can be carried out using 3M's lead testing swabs (Lead Check ${ }^{T M}$ ), and this is practiced by many labs. This colorless swab contains a proprietary chemical indicator mixture that changes color from colorless to red in the presence of lead. The manual states that "pale pink indicates the presence of a minimum of 1-2 $\mu \mathrm{g}$ of lead ion $\left(\mathrm{Pb}^{2+}\right)$ on the area tested." Yet, it is not clear if the swab reacts exclusively to $\mathrm{Pb}^{2+}$ or if other forms of lead, other elements and material combinations may trigger a color change as well. Importantly, the test was developed as a "Qualitative Spot Test Kit for Lead in Paint" with a sensitivity of $1 \mathrm{mg} / \mathrm{cm}^{2}$. A more detailed report (sponsored by $3 \mathrm{M}$ ) on the performance evaluation of this qualitative test can be found in 
reference. ${ }^{18}$ It is clear from this report that only paint containing $\mathrm{Pb}^{2+}$ was used as part of the testing protocol $\left(\mathrm{PbCO}_{3}, \mathrm{PbCrO}_{4}\right)$. To evaluate the effectiveness of the $3 \mathrm{M}$ testing swabs in our lab environment we compared the results of this test with a quantitative in-house test that consisted of rubbing a cotton swab on a contaminated area and post-analysis of the cotton swab using inductively coupled plasma spectroscopy (ICP). We then tested the same areas with both techniques after successive decontamination steps using a commercial lead cleaning detergent. A detailed description of the contamination testing and decontamination procedure can be found in the Supporting Information. The above two procedures (testing for contamination and decontamination) were utilized in conjunction with side-by-side comparison of 3M's Lead Check kits on various locations throughout a range of labs. The Lead Check swabs were used (as per manufacturer instructions) after the contamination testing procedure was performed but before the decontamination procedure was done. The results are listed in Table 2. Additional results are shown in the Supporting Information. We used other lead testing kits, for example, the Full Disclosure Kit from SKC but the results were not conclusive.

In addition to analyzing methods for testing lead contamination and decontamination levels, a head-to-head comparison to determine the effectiveness of a few chosen cleaners was performed (Figure 2). Hygenall's Lead Off and Esca Tech's D-Lead were selected as they have been used in other Perovskite labs for lead decontamination purposes. Standard Dial liquid hand soap (dilution of $4 \mathrm{~mL} / \mathrm{L}$ of deionized water) was also used to determine the effectiveness of a standard and readily available soap/detergent. The results are listed in Table 3.

The Lead Check swabs show considerable variability in performance. This variability could possibly be due to the valence state of the lead under evaluation (elemental $\mathrm{Pb}, \mathrm{Pb}^{2+}$ or $\mathrm{Pb}^{4+}$ ). Even at triple digit ppm values, as measured by ICP, the swabs barely exhibited a red color, while in the case of the fume hood results, where ICP showed sub-single digit ppm values, the swabs turned red. This suggests that the swabs may only be specific for a certain ionic species of lead (most likely $\mathrm{Pb}^{2+}$ ), or the swabs are detecting another metal. The $3 M$ Lead Check swabs have no visible expiration date and, based on the results of the present study, may not be the most suitable method of lead detection for laboratory environments or applications. Similarly, a previous study by Korfmacher et al. reported a false negative rate of $64 \%$ and concluded that Lead Check swabs could not reliably detect levels of lead in dust above $40 \mu \mathrm{g} / \mathrm{ft}^{2} .{ }^{19}$ We note that in order to obtain quantitative masses of lead per surface area probed, the application of a smear tab (e.g., from 
Table 2. Lead contamination detection level comparisons - ICP vs. Lead Check swabs. A new test swab was used after every cleaning step. The explanation in parentheses refers to the cleaning method used.

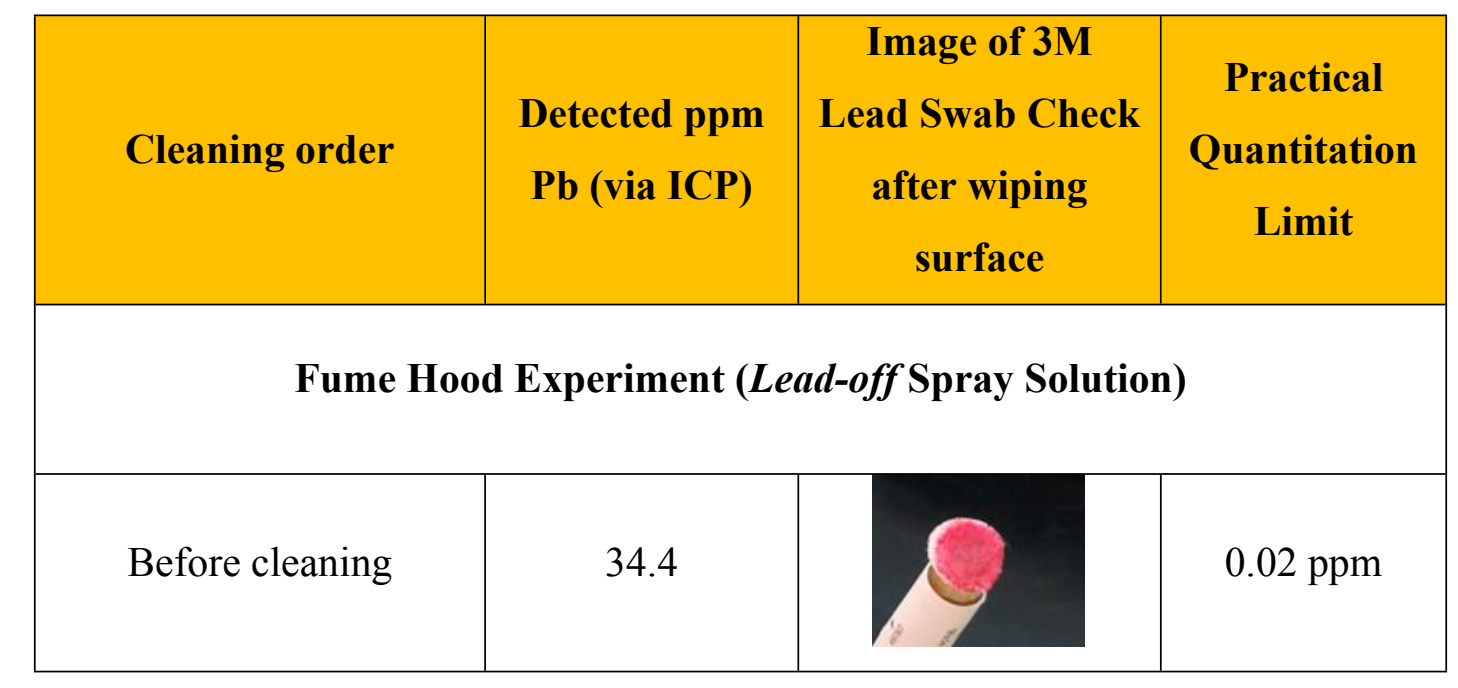

\begin{abstract}
Whatman) across a well-defined area, weigh out of the amount of material adsorbed by the tab and then calculation of the mass of lead on that tab from a ppm measurement like ICP would be required. This would allow a comparison with housekeeping standards for lead as stipulated for example by the U.S. Department of Housing and Urban Development (the permissible amount of leaded dust on floors was just changed from 40 to $\left.10 \mu \mathrm{g} / \mathrm{ft}^{2}\right){ }^{20}$
\end{abstract}

When evaluating the performance of the cleaners (Figure 2 and Table 3), the results show that they are effective in reducing lead contamination levels, with some noticeable differences. The Dial liquid hand soap was exceptionally effective and considering its wide availability made it, in our opinion, clearly the best overall choice among the three tested options. Of the specialized cleaners, the Lead Off performed best in our tests, whereas the D-Lead was not as effective. Importantly, the experimental results clearly illustrate that a single cleaning can significantly reduce the contamination levels. This should reassure lab users that lead decontamination can be effectively accomplished. 


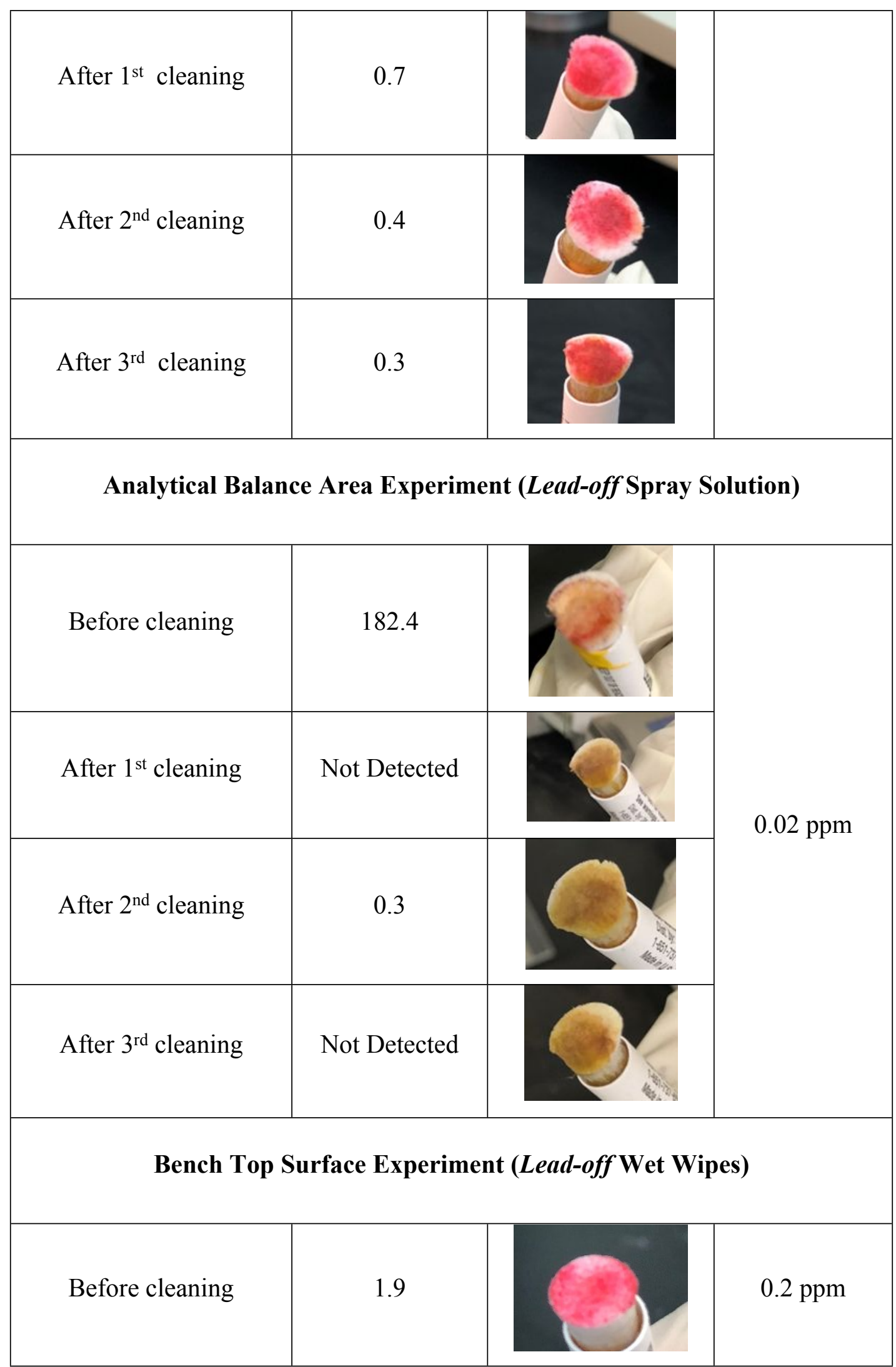



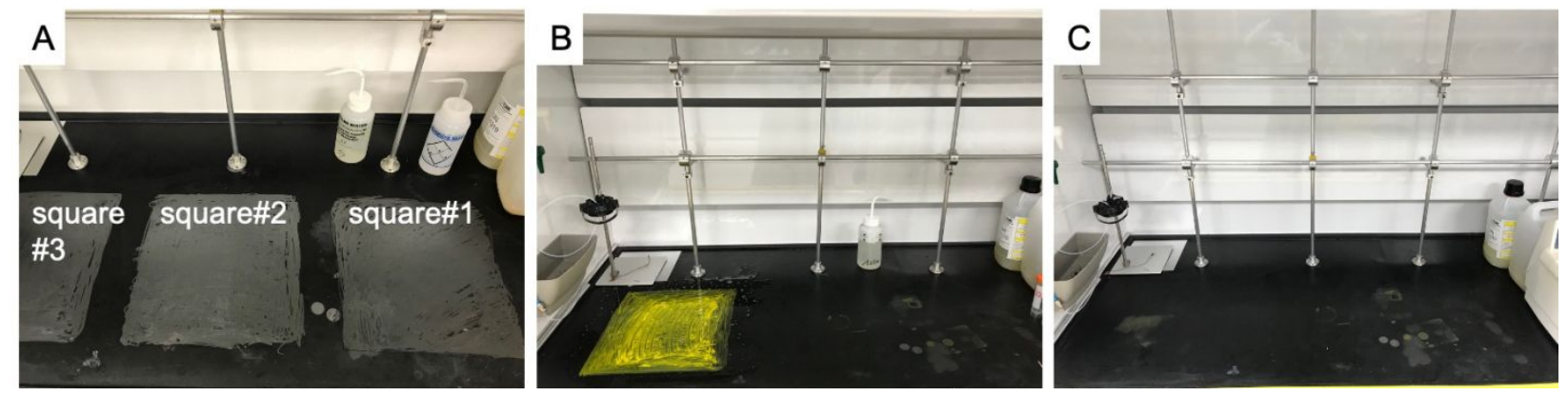

Figure 2. Probing the effectiveness of detergents/soap to remove lead from the surface of a fume hood. A) $1 \mathrm{ml}$ of a perovskite precursor solution in a 4:1 mixture of Dimethylformamide and Dimethyl Sulfoxide containing Lead Bromide, Lead Iodide, Cesium Iodide, Methylammonium Bromide, Formamidinium Iodide (all with a $1.7 \mathrm{M}$ concentration) was dropped on and spread across similar areas in the form of squares. The surface was blow dried using a heat gun. B) Photograph after cleaning the right and center piece and before cleaning the left contaminated piece. The contaminated area on the left turned yellowish upon sprinkling the area with soap water (Dial soap) but lead was removed effectively after only one cleaning cycle (Figure 2C). C) Photograph of the three purposely contaminated areas after completing the cleaning cycles described in Table 3. 
Table 3. Comparison of performance of lead decontamination cleaners. Square \#1, \#2, \#3 corresponds to the areas shown in Figure 2A from right to left.

\begin{tabular}{|c|c|c|c|}
\hline Cleaner & Description & $\underset{\mathbf{P b}}{\mathbf{p p m}}$ & $\begin{array}{c}\text { Practical } \\
\text { Quantitation } \\
\text { Limit }\end{array}$ \\
\hline \multicolumn{4}{|c|}{ Square \#1 } \\
\hline Lead-Off & Before cleaning & 2261 & \multirow{5}{*}{$0.02 \mathrm{ppm}$} \\
\hline Lead-Off & After $1^{\text {st }}$ cleaning & 159 & \\
\hline Lead-Off & After $2^{\text {nd }}$ cleaning & 88 & \\
\hline Lead-Off & $\begin{array}{l}\text { After } 3^{\text {rd }} \text { heavy } \\
\text { cleaning }\end{array}$ & 24 & \\
\hline Lead-Off & $\begin{array}{l}\text { After } 4^{\text {th }} \text { heavy } \\
\text { cleaning }\end{array}$ & $<0.2$ & \\
\hline \multicolumn{4}{|c|}{ Square \#2 } \\
\hline D-Lead & Before cleaning & 1918 & \multirow{6}{*}{$0.02 \mathrm{ppm}$} \\
\hline D-Lead & After $1^{\text {st }}$ cleaning & 316 & \\
\hline D-Lead & After $2^{\text {nd }}$ cleaning & 339 & \\
\hline D-Lead & After $3^{\text {rd }}$ cleaning & 261 & \\
\hline D-Lead & After $4^{\text {th }}$ cleaning & 104 & \\
\hline $\begin{array}{l}\text { *After heavy Lead-Off use } \\
\left(2^{\text {nd }} \text { square }\right)\end{array}$ & After $5^{\text {th }}$ cleaning & $<0.2$ & \\
\hline \multicolumn{4}{|c|}{ Square \#3 } \\
\hline Dial Solution & Before cleaning & 1878 & \multirow{5}{*}{$0.02 \mathrm{ppm}$} \\
\hline Dial Solution & After $1^{\text {st }}$ cleaning & 20 & \\
\hline Dial Solution & After $2^{\text {nd }}$ cleaning & $<0.2$ & \\
\hline Dial Solution & After $3^{\text {rd }}$ cleaning & $<0.2$ & \\
\hline Dial Solution & $\begin{array}{l}\text { After heavy cleaning } \\
\text { with dial solution }\end{array}$ & $<0.2$ & \\
\hline
\end{tabular}

\section{Lab Decontamination and Waste Management}


We faced the challenge of decontaminating a lab and several gloveboxes that were previously heavily used for perovskite research. Several conclusions emerged from this experience. Perhaps the most important one is that it is possible to decontaminate lead salts on a large scale to the limit of the ICP's detection $(<0.1 \mathrm{ppm})$ using conventional cleaning methods. As shown in the previous section, commercial lead detergent or even hand soap can remove lead stains. Other reports suggest adding a lead binding agent to soap solution to enhance the efficiency with which lead is removed. A common binder is TSP (trisodium phosphate). This is a component of most lead detergents. We advise rinsing off the surface with water after cleaning with detergent to fully remove the soap and thus any remaining lead residue. Several wet cleaning cycles with detergent might be necessary until left with an untraceable amount of lead. Planning the decontamination is critical, starting with cleaning supply, contamination detection, waste handling and personal protective lab gear that is impermeable to particulates and chemically resistant, much beyond common lab PPE. We opted for full body hooded coveralls and boot covers from DuPont's Tyvek IsoClean product line. We used NIOSH approved respiratory masks with solvent and particulate (P100) filter from Honeywell. It is advisable to choose respiratory filters consisting of a HEPA cartridge and a charcoal filter. Here, PPE should be considered as one-time use only. Respiratory filters can be reused and should be replaced following manufacturer instructions.

Usually, the decontamination process will accumulate a large amount of contaminated waste and it is important to have a waste management strategy in place that will allow appropriate hazardous waste disposal. After decontaminating an area, a reliable test should be applied to ensure that lead has been effectively removed. For a quick qualitative test, $3 \mathrm{M}$ swabs are an acceptable option. More reliable testing will require sophisticated chemical analytics like ICP. Finally, protective clothing should be removed with great care before exiting the lab. It should be disposed of together with other contaminated waste material.

In a future perspective, we emphasize that the recovery of lead as well as other hazardous materials such as cadmium, antimony, fluorine-based polymers and other elements/components (e.g., aluminum, silver, copper, indium, gallium, tellurium, glass) used in manufacturing solar panels is critically important from an environmental, safety and global health perspective. A $1 \mathrm{GW}$ installation of perovskite solar panels would generate an estimated $3450 \mathrm{~kg}$ of lead waste 
at the end of its lifecycle (assuming a $500 \mathrm{~nm}$ film and 20\% power conversion efficiency). In most countries, waste associated with PV panels falls under the classification of "general waste", which may be classified as hazardous waste. In the US, for instance, there is no dedicated national program or requirement to safely dispose of solar panels. The regulations fall under the Resource Conservation and Recovery Act (RSCA), which is enforced by the US Environmental Protection Agency (EPA). The European Union (EU) was the first region to adopt PV-specific waste regulations. The EU imposes that PV module manufacturers that sell to the European market finance the costs of collecting and recycling end-of-life PV panels. This mandate is expected to create a reliable and economically viable recycling industry. The International Renewable Energy Agency (IRENA) and the International Energy Agency's Photovoltaic Power Systems Programme (IEA-PVPS) are taking leading roles in the context of regulating the disposal of end-of-life photovoltaic panels. ${ }^{21}$

\section{Medical Surveillance}

Blood testing is a necessary means to monitor the levels of lead in the body. ${ }^{22}$ It is a predictive indicator for medical anomalies associated with lead. Recent results from studies looking into health implications at low lead concentrations in blood carried out under the supervision of NIOSH and AOEC, prompted our institution to adopt guidelines and reference standards based on these two organizations to monitor occupational exposure to lead in our labs. ${ }^{23}$ Based on these recent studies, NIOSH advises $5 \mu \mathrm{g} / \mathrm{dL}$ (five micrograms per deciliter) as the reference blood lead level for adults. At our institution, every user of our facilities working with lead-based materials is required to undergo medical surveillance and commits to adhering to the following procedure:

a) Blood Lead Level (BLL) testing:

i. Shall be performed before the first assignment to an area that contains lead-based materials. This value shall be used as a future reference baseline for the individual.

ii. After 6 months of the first assignment. 
iii. Once a year for individuals who had a Blood Lead Level (BLL) of less than 5 $\mu \mathrm{g} / \mathrm{dL}$ in two consecutive tests or every 6 months for individuals with BLL $>5$ $\mu \mathrm{g} / \mathrm{dL}$ during the preceding 6 months.

iv. Individuals will not be permitted to carry out lead-based work, if a BLL of more than $10 \mu \mathrm{g} / \mathrm{dL}$ is obtained during medical surveillance. Re-exposure to lead-based work should not begin again until the value has dropped to below $10 \mu \mathrm{g} / \mathrm{dL}$.

In our institution's SOP,${ }^{15}$ we ensure that the blood test analysis only monitors levels of lead and no other vital factors.

So far, we have performed 62 blood tests within a period of 2 years. The highest reported value was $3.6 \mu \mathrm{g} / \mathrm{dL}$, still well below the established reference lead blood level. We believe it is important to understand whether under a perovskite research environment such as in our labs any accumulative effects are observed within at least one full $\mathrm{PhD}$ cycle.

\section{Recommendations}

Perovskite labs should draft Standard Operating Procedures for working with lead compounds to ensure a safe working environment. We emphasize the importance of a thorough cleaning, ideally after every use of a surface or end of the day, similar to those employed in a microbiology lab for example. This will decrease lead contamination levels and therefore decrease the risk of lead exposure as well.

Perovskite labs must monitor and supervise their lead use and cleanup to include reliable lead testing like ICP swab tests. Labs should institute random sampling of surfaces to be performed semi-annually with results recorded in their Laboratory Safety Plans and be acted upon. Results should also be sent to EHS/HSE colleagues for further review.

Based on the results of the tests performed in our laboratories, and the ease at which the proven levels can be achieved in just one cleaning, we recommend that a threshold level of $<5 \mathrm{ppm}$ lead be stated as the allowable level of lead contamination. Anything higher should require immediate cleaning.

This contamination action level ( $<5 \mathrm{ppm}$ lead) was chosen, based on 3 factors: 
1. The absence of clear, accepted, regulatory standard for this type of lead work.

2. It is conceivable that the pure form of lead salts that researchers are using in perovskite research is more bioactive and therefore more hazardous than lead contaminated paint, where lead $\mathrm{Pb}^{2+}$ is embedded in a material mixture.

3. The ongoing experimental evidence to date shows that $<5 \mathrm{ppm}$ lead can be achieved in just one cleaning step.

\begin{abstract}
Although it can be argued that such a threshold is rather arbitrary because no threshold for the health effects of lead is demonstrated, we argue that analytically a contamination level of $5 \mathrm{ppm}$ can be readily and accurately measured and provides a benchmark for successful prevention. These guidelines should be reevaluated if further information is forth coming.

Overall, the set of data presented here clearly illustrates the importance of cleaning frequently to reduce lead contamination and exposures. We believe that by implementing a good housekeeping plan paired with the recommendations put forward in this text, it is possible to create the level of awareness needed to establish a safe working environment in the context of perovskite research. It is our expectation that labs around the world will use these guidelines to review and elevate their own safety standards.
\end{abstract}

\title{
Acknowledgements
}

We would like to acknowledge helpful discussions with George Evans (NREL), Craig Combe (KAUST Solar Center), Natashia Fourie (KAUST, HSE) and the continuous support from KAUST Health. Figure 1 was created by Heno Hwang, scientific illustrator at King Abdullah University of Science and Technology (KAUST).

\section{Supporting Information Available:}

Detailed contamination Testing Procedures; additional lead contamination detection level comparisons. This material is available free of charge via the Internet at http://pubs.acs.org. 


\section{Ethics declarations/Competing interests}

We note that we do not have any commercial interest in the products mentioned here and that other alternatives may be available on the market.

\section{References}

(1) Snaith, H. J. Present Status and Future Prospects of Perovskite Photovoltaics. Nat. Mater. 2018, 17 (5), 372-376.

(2) Correa-Baena, J.-P.; Abate, A.; Saliba, M.; Tress, W.; Jacobsson, J. T.; Grätzel, M.; Hagfeldt, A. The Rapid Evolution of Highly Efficient Perovskite Solar Cells. Energy \& Environmental Science 2017, 10 (3), 710-727.

(3) Plog, B. A.; Quinlan, P. J. Fundamentals of Industrial Hygiene, 6th Edition.; Plog, B. A., Quinlan, P. J., Eds.; National Safety Council, 2012.

(4) Tchounwou, P. B.; Yedjou, C. G.; Patlolla, A. K.; Sutton, D. J. Molecular, Clinical and Environmental Toxicology, Volume 3: Environmental Toxicology. 2012, 133-164.

(5) Agency for Toxic Substances and Disease Registry. Toxicological Profile for Lead, 2019. Available online at: https://www.atsdr.cdc.gov/toxprofiles/tp13.pdf (accessed July 25, 2020)

(6) Babayigit, A.; Ethirajan, A.; Muller, M.; Conings, B. Toxicity of Organometal Halide Perovskite Solar Cells. Nat. Mater. 2016, 15 (3), 247-251.

(7) National Toxicology Program Monograph. Health Effects of Low-Level Lead, 2012. Available online at:

https://ntp.niehs.nih.gov/ntp/ohat/lead/final/monographhealtheffectslowlevellead_newissn_5 08.pdf (accessed July 25, 2020)

(8) Stoughton, R. B.; Fritsch, W. Influence of Dimethylsulfoxide (DMSO) on Human Percutaneous Absorption. Arch. Dermatol. 1964, 90 (5), 512. 
(9) Agency for Toxic Substances and Disease Registry. Case Studies in Environmental Medicine, 2017. Available online at: https:/www.atsdr.cdc.gov/csem/lead/docs/CSEMLead_toxicity_508.pdf (accessed July 25, 2020)

(10) National Research Council; Division on Earth and Life Studies; Board on Environmental Studies and Toxicology; Committee on Potential Health Risks from Recurrent Lead Exposure of DOD Firing Range Personnel; Committee on Toxicology. Potential Health Risks to DOD Firing-Range Personnel from Recurrent Lead Exposure, 2012. Available online at: https://doi.org/10.17226/18249 (accessed July 25, 2020)

(11) Occupational Safety and Health Administration (OSHA). Lead in Construction, 2004.

(12) Lanphear, B. P.; Rauch, S.; Auinger, P.; Allen, R. W.; Hornung, R. W. Low-Level Lead Exposure and Mortality in US Adults: A Population-Based Cohort Study. Lancet Public Heal. 2018, 3 (4), e177-e184.

(13) O’Connor, D.; Hou, D.; Ok, Y. S.; Lanphear, B. P. The Effects of Iniquitous Lead Exposure on Health. Nat. Sustain. 2020, 3 (2), 77-79.

(14) Association of Occupational and Environmental Clinics (AOEC). Medical Management Guidelines for Lead-Exposed Adults, 2007. Available online at: http://www.aoec.org/documents/positions/MMG_FINAL.pdf?id=10.26616/NIOSHPUB2012 164 (accessed July 25, 2020)

(15) https://ksc.kaust.edu.sa/Pages/Lead-Safety.aspx (accessed July 25, 2020)

(16) Schwope, A. D.; Randel, M. A.; Broome, M. G. Dimethyl Sulfoxide Permeation through Glove Materials. Am. Ind. Hyg. Assoc. J. 1981, 42 (10), 722-725.

(17) Center for Disease Control and Prevention. How to Remove Gloves. Available online at: https://www.cdc.gov/vhf/ebola/pdf/poster-how-to-remove-gloves.pdf (accessed July 25, 2020)

(18) Buehler, S.; Rhoda, D. 3M Leadcheck Swabs Qualitative Spot Test Kit for Lead in Paint, 2012. Available online at: https://www.epa.gov/sites/production/files/documents/3Mleadcheck-report.pdf (accessed July 25, 2020) 
(19) Korfmacher, K. S.; Dixon, S. Reliability of Spot Test Kits for Detecting Lead in Household Dust. Environ. Res. 2007, 104 (2), 241-249.

(20) U. S. Department of Housing and Urban Development. Office of Healthy Homes and Lead Hazard Control. Guidelines for the Evaluation and Control of Lead-Based Paint Hazards in Housing, 2012. Available online at:

https://www.hud.gov/sites/documents/SECOND_EDITION_2012.PDF (accessed July 25, 2020)

(21) IRENA and IEA-PVPS. End-of-Life Management: Solar Photovoltaic Panels. International Renewable Energy Agency and International Energy Agency Photovoltaic Power Systems, 2016. Available online at:

https://www.irena.org/documentdownloads/publications/irena_ieapvps_end-oflife_solar_pv_panels_2016.pdf(accessed July 25, 2020)

(22) Kosnett, M. J.; Wedeen, R. P.; Rothenberg, S. J.; Hipkins, K. L.; Materna, B. L.; Schwartz, B. S.; Hu, H.; Woolf, A. Recommendations for Medical Management of Adult Lead Exposure. Environ. Health Persp. 2007, 115 (3), 463-471.

(23) The National Institute for Occupational Safety and Health (NIOSH). Adult Blood Lead Epidemiology and Surveillance (ABLES). Available online at: https://www.cdc.gov/niosh/topics/ables/description.html (accessed July 25, 2020) 


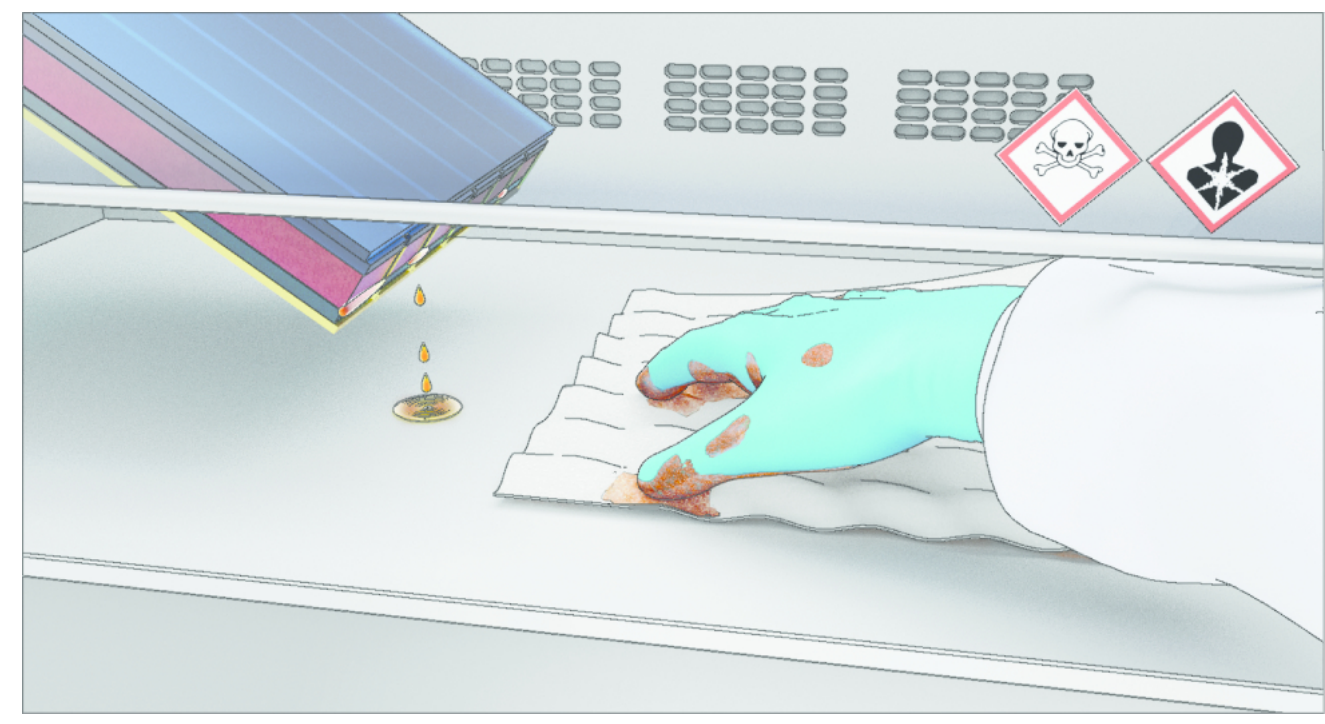

This is a table of content graphic (TOC) 